Article

\title{
Combustion of Miscanthus: Composition of the Ash by Particle Size
}

\section{Christof Lanzerstorfer}

School of Engineering/Environmental Sciences, University of Applied Sciences Upper Austria, Stelzhamerstraße 23, A-4600 Wels, Austria; c.lanzerstorfer@fh-wels.at; Tel.: +43-50804-43220

Received: 19 November 2018; Accepted: 1 January 2019; Published: 7 January 2019

\begin{abstract}
Miscanthus is an energy crop considered to show potential for a substantial contribution to sustainable energy production. In miscanthus combustion, $2.0 \%$ to $3.5 \%$ of the mass of the fuel remains as ash. This ash is less contaminated by heavy metals than ash from wood combustion. The concentrations are well below the typical limit concentrations for use as a soil conditioner on agricultural land and forests. The potassium concentration in the investigated miscanthus ash of $14.1 \% \mathrm{~K}_{2} \mathrm{O}$ was significantly higher than the typical concentration of potassium in ashes from wood combustion $\left(3 \%\right.$ to $\left.7 \% \mathrm{~K}_{2} \mathrm{O}\right)$. However, in comparison to wood ashes, only very little enrichment of potassium in the fine size fractions of miscanthus ash was found. For most of the other elements, the enrichment in the fine size fractions was also low. Therefore, the production of a potassium-rich material by classification for the production of potassium fertilizer is not feasible. The absence of such an enrichment can be explained on the one hand by the significantly lower combustion temperature in the miscanthus combustion plant and, on the other hand, by the higher molar ratio of $\mathrm{K}$ to $\mathrm{Cl}$ and the low ratio of $\mathrm{K}$ to $\mathrm{Si}$. Thus, the most sensible utilization of miscanthus ash is its direct recycling to the soil such as where the miscanthus plants are grown.
\end{abstract}

Keywords: biomass combustion; miscanthus; ash; potassium; heavy metals; particle size

\section{Introduction}

The combustion of biomass like Miscanthus giganteus is considered to be almost carbon dioxide neutral. The carbon dioxide produced in the combustion process has been fixed by photosynthesis during the growth of the plants [1]. Miscanthus is one of the energy crops that shows substantial potential for sustainable energy production [2]. Miscanthus can be used as a fuel in combustion plants [3] but also the production of bio-fuels from miscanthus is investigated [4]. However, in a recent study, it was concluded that, for power generation from miscanthus biomass, the most favorable way is combustion [5].

Besides the mentioned potential, the use of miscanthus in Europe is low and the cultivation area is even decreasing because production costs for miscanthus are presently too high to compete commercially with fossil fuels as a source of energy [5]. At present, about 20,000 ha of miscanthus are commercially grown in the EU, with approximately half of it in the UK [5]. The main production areas for miscanthus in Austria are located in Upper Austria and Lower Austria [6]. The dry biomass yield depends on the soil quality and meteorological parameters, especially water supply and temperature. In Austria, on good soil, the yield is in the range of 15-22 $t$ dry mass per hectare [7].

In the combustion of miscanthus, the inorganic constituents remain as ash. The typical total ash content of miscanthus is in the range of $2.0 \%$ to $3.5 \%$ [8-10]. In grate-fired combustion systems, the coarser ash is discharged as bottom ash while the finer ash fraction leaves the combustion zone with the off-gas as fly ash. Because of the low ash melting temperature, which is strongly correlated 
with the potassium and chloride content of the ash, the combustion temperature is kept as low as possible [11].

In many countries, the ash from the combustion of chemically untreated biomass is utilized as a soil conditioner on agricultural land and forests. However, country-specific limit concentrations for heavy metals have to be observed [12-14]. The recycling of biomass ashes to the soil where the biomass was grown is proposed to help to close the cycles of the plant nutrients $\mathrm{P}, \mathrm{K}, \mathrm{Ca}$, and $\mathrm{Mg}$ [15]. In a recent study, the positive effect of biomass ash on the chemical properties of the soil and the yield of miscanthus has been demonstrated [16].

Another use of biomass ash has been suggested recently [17]. In this study, the finest fraction from wood combustion fly ash was separated by classification to produce a potassium-rich material $\left(\mathrm{K}_{2} \mathrm{O}>35 \%\right)$ for the production of potassium fertilizer.

In the literature, little data is available on the chemical composition of ash from the combustion of miscanthus. In two studies, the data were obtained from ash samples produced by combustion of small samples of miscanthus in a muffle furnace at $550{ }^{\circ} \mathrm{C}$ for $3 \mathrm{~h}$ and at $400{ }^{\circ} \mathrm{C}$ for $8 \mathrm{~h}[8,9]$. A third study reported the ash content of miscanthus plants and the concentration data for some components in miscanthus plants [18]. From this data, the expected content of the components in the ash can be calculated. In a recent study, ash composition data from an industrial scale combustion plant were reported [19]. No data was found in the literature for the variations of the composition of ash from the combustion of miscanthus by particle size.

For fly ash from wood combustion enrichment of potassium and some heavy metals in the finest ash fractions has been reported [20,21]. This enrichment can be explained by volatilization and re-condensation of these components during combustion and re-cooling of the off-gas. Thereby, volatile elements are enriched in the finer size fractions due to the higher specific surface area of these size fractions. If the utilization of the miscanthus ash in fertilizer production is intended, enrichment of $\mathrm{K}$ in the fine fraction would be beneficial because this would allow production of a highly concentrated fraction by classification. In contrast, when the ash is used as a soil conditioner, an increased concentration of heavy metals in the finest fractions is disadvantageous because the finest fractions might be dispersed partly into the atmosphere, especially when the ash is not agglomerated before spreading.

The aim of this study was to investigate the size-dependence of the concentrations of $\mathrm{K}$ and some heavy metals in ash from the combustion of miscanthus in a full-scale combustion plant. The size dependence of these components is expected to be somewhat different compared to that in wood combustion ash due to the lower combustion temperature and the different composition of the ash.

\section{Materials and Methods}

An ash sample of about $2 \mathrm{dm}^{3}$ was obtained from a district heating boiler with a thermal capacity of $300 \mathrm{KW}_{\text {th }}$ using miscanthus as fuel. The miscanthus plants were grown in Lower Austria $(250 \mathrm{~m}$ a.s.l.). In April, the culm material was harvested leaving leaves out on the soil. The harvested material was chopped and stored under an open air roof. The combustion plant consists of a boiler with a grate firing system. In the plant, the combustion temperature was kept as low as possible to avoid operation problems caused by the comparatively low melting point of the ash. In the boiler, the temperature measured about $1 \mathrm{~m}$ above the combustion grate was approximately $600{ }^{\circ} \mathrm{C}$. The off-gas from the combustion is de-dusted by a cyclone. The separated fly ash is discharged together with the bottom ash from the combustion grate as a mixed ash fraction. This ash is recycled to the soil where the biomass is grown.

For sequential dry classification of the ash sample, a laboratory air classifier 100 MZR from Hosokawa Alpine was used. In the first classification step, the finest size fraction was separated from the bulk, which was used subsequently as feed material in the next classification step where the classifier was operated at reduced speed. This procedure was repeated twice. The details of such a sequential classification procedure are described in the literature [22]. 
For various laboratory tests, the volume of the samples was reduced to a suitable volume using sample dividers, which were applied repeatedly (Haver\&Boecker HAVER RT and Quantachrome Micro Riffler).

The particle size distribution of the ash samples was measured using a laser diffraction instrument with dry sample dispersion (Sympatec HELOS/RODOS). A Sympatec SiC-P600'06 standard was used to check the calibration of the instrument. The mass median diameters $d_{50}$ were derived from the measured particle size distributions. A density of the particles independent of the size was assumed.

The concentrations of $\mathrm{S}, \mathrm{P}, \mathrm{Cl}, \mathrm{Br}$, and of various metals ( $\mathrm{Al}, \mathrm{As}, \mathrm{Ba}, \mathrm{Bi}, \mathrm{Ca}, \mathrm{Cd}, \mathrm{Co}, \mathrm{Cr}, \mathrm{Cu}, \mathrm{Fe}, \mathrm{Ga}$, $\mathrm{Ge}, \mathrm{Hg}, \mathrm{K}, \mathrm{Mg}, \mathrm{Mn}, \mathrm{Mo}, \mathrm{Na}, \mathrm{Ni}, \mathrm{Pb}, \mathrm{Rb}, \mathrm{Sb}$, Se, Si, Sn, Sr, Ta, Ti, Th, Tl, V, Y, and $\mathrm{Zn}$ ) were measured using an XRF spectrometer, type SPECTRO XEPOS from AMETEK. The instrument mode used in the analysis of the ash samples was TurboQuant. The calibration of the instrument was checked using an MCA fusion tablet. The total carbon content (TC) was measured with a vario TOC select system (Elementar Analysensysteme) in solid mode. A 4.1\% TOC/TC soil standard was used for the calibration of the system.

The microscopic images of the particles were taken with a MIRA3 scanning electron microscope (TESCAN).

The contamination of the ash by heavy metals can be assessed by comparing with legal limit values of various countries for use of the ash as a soil conditioner [12-14]. Another general method for assessment of contamination levels of heavy metals is provided by the Geo-accumulation Index ( $\left.I_{\text {geo }}\right)$ as introduced by Müller [23]. It is calculated by Equation (1).

$$
I_{\text {geo }}=\log _{2}\left(\frac{C_{n}}{1.5 \cdot B_{n}}\right)
$$

where $C_{n}$ is the mass concentration of the target component in the unclassified ash sample. The concentration of the target component in the upper crust [24] was used for the geochemical background concentration $B_{n}$. The background matrix correction factor of 1.5 is used due to lithological variability. The values of $I_{\text {geo }}$ can be classified into seven categories [23], from unpolluted $\left(I_{\text {geo }} \leq 0\right)$ to extremely polluted $\left(I_{g e o}>5\right)$.

For the characterization of the concentration variation of various components by particle size power functions of the type $c, \sim 1 / d^{N}$ can be used [25]. For each component, the exponent $N$ can be obtained by linear regression. The higher the value of $N$, the more pronounced is the concentration increase in the fine size fractions and the depletion in the coarse size fractions. In the calculation, the mass median diameter $d_{50}$ was used as the characteristic particle size of each size fraction. When the mass concentration $C_{n, j}$ of the target component in size fraction $j$ is divided by $C_{n}$, enrichment factors $E F$ are obtained, which enables an easier comparison between different heavy metals (Equation (2)).

$$
E F\left(d_{50}\right)=\frac{C_{n, j}\left(d_{50}\right)}{C_{n}}=K^{*} \cdot \frac{1}{\left(d_{50, j}\right)^{N}}
$$

The behavior of potassium during the combustion process was studied theoretically calculating the thermodynamic equilibrium in dependence of the temperature. For this calculation, the program HSC Chemistry ${ }^{\circledR} 5.1$ (Outotec Oy, Pori, Finland) was used. In the calculation, the following approximate composition of the combustion off-gas was chosen: 70 vol. $\% \mathrm{~N}_{2}, 8$ vol. $\% \mathrm{O}_{2}, 14 \mathrm{vol} . \% \mathrm{CO}_{2}$, and 8 vol. $\%$ $\mathrm{H}_{2} \mathrm{O}$. The ash composition was approximated with the main elements of the ash $(\mathrm{Si}, \mathrm{Ca}, \mathrm{O}$, and $\mathrm{K})$ using results from the ash analysis. Additionally, $\mathrm{Cl}$ and $\mathrm{S}$ were considered because of their important role in volatilization of potassium. However, these calculations can only be used indicatively because equilibrium will not be reached in a combustion process due to the short residence time. 


\section{Results}

\subsection{Particle Size of the Ash and the Ash Fractions Produced}

The mass fractions and the mass median diameters for the five size fractions produced are summarized in Table 1. The TC content of the samples is also given in Table 1 . The ash content of the samples results from 100-TC. The particle size distributions of the size fractions are shown in Figure 1. As expected for a combined bottom ash and cyclone ash sample, the most prominent size fraction was the coarsest fraction.

Table 1. Data of the ash size fractions produced.

\begin{tabular}{cccc}
\hline Size Fraction & Mass Fraction in $\%$ & Mass Median Diameter $\boldsymbol{d}_{\mathbf{5 0}}$ in $\boldsymbol{\mu m}$ & TC Content in $\%$ \\
\hline SF 1 & 6.5 & 1.9 & 7.4 \\
SF 2 & 7.5 & 5.2 & 6.0 \\
SF 3 & 10.7 & 12 & 3.5 \\
SF 4 & 25.6 & 27 & 1.9 \\
SF 5 & 49.7 & 76 & 1.0 \\
\hline
\end{tabular}

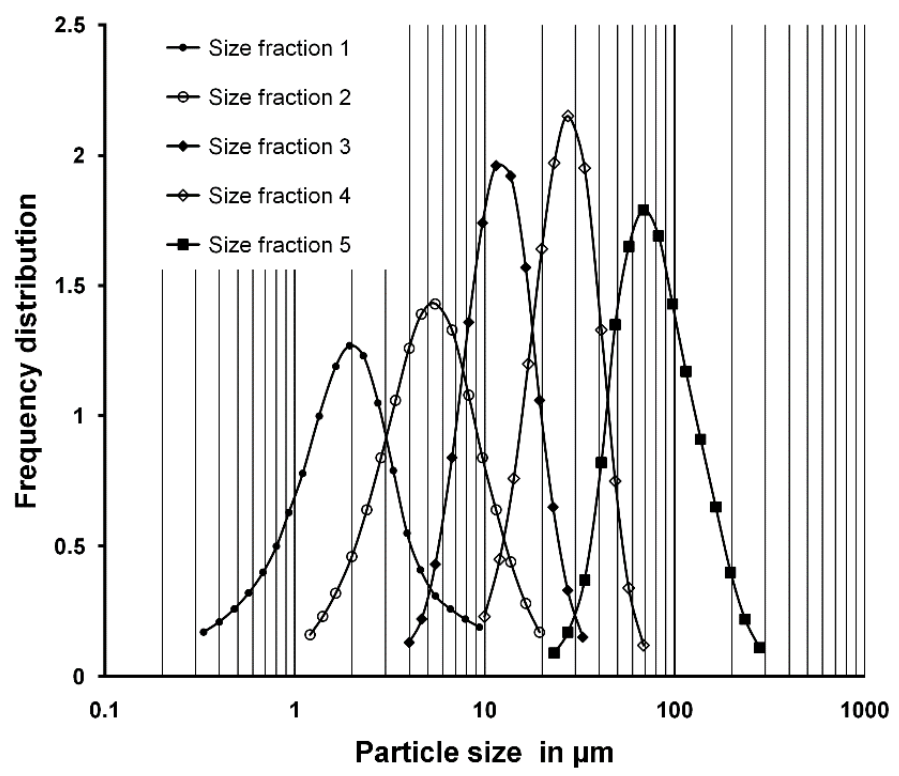

Figure 1. Particle size distribution of the size fractions produced from the ash by air classification.

Microscopic images of particles from the different size fractions are shown in Figure 2. Regardless of the size fraction, all the particles shown in the images are angular and cornered. None of the individual particles is spherical, which was found for some of the ash particles from the combustion of wood [21]. This indicates that none of the particles was molten during combustion, which is due to the comparatively low combustion temperature in the miscanthus combustion plant. 


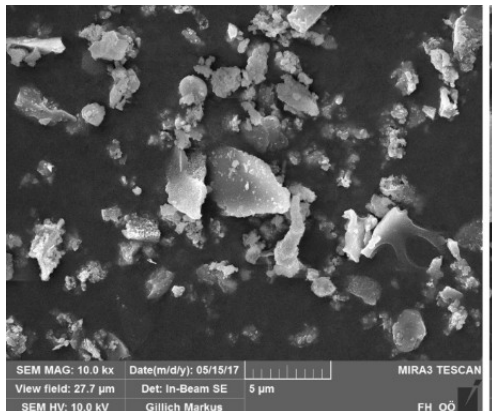

Size fraction 1

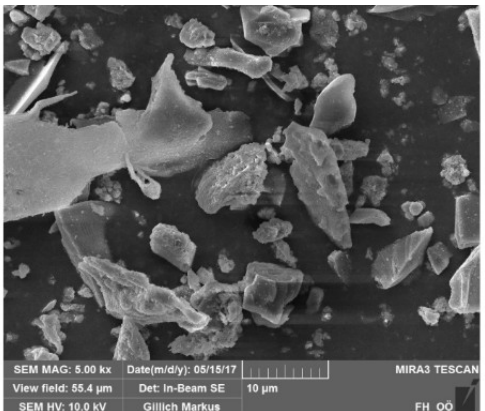

Size fraction 2

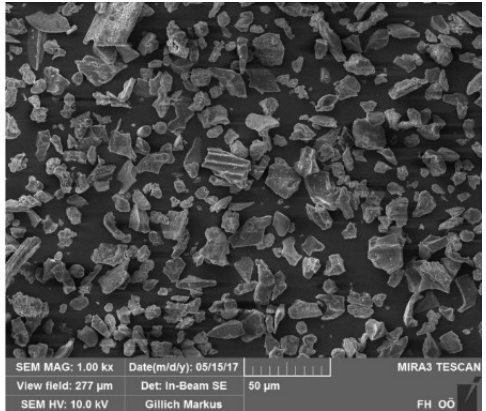

Size fraction 3

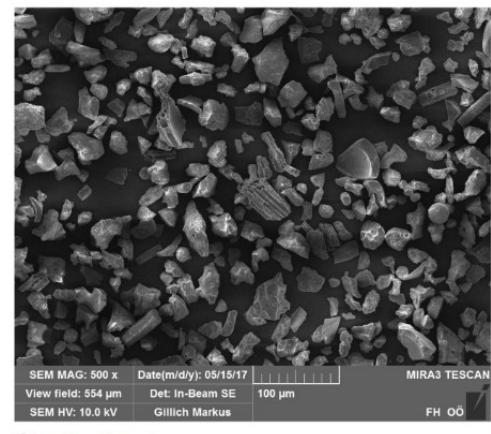

Size fraction 4

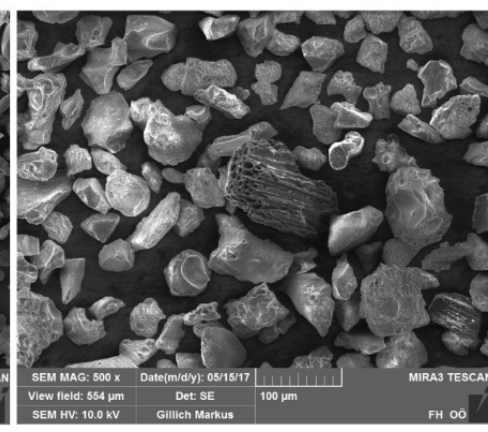

Size fraction 5

Figure 2. Microscopic images of particles from the different size fractions.

\subsection{Chemical Analysis of the Ash Sample and the Size Fractions Produced}

The chemical analysis of the ash sample is shown in Tables 2 and 3 together with the analysis of the size fractions. The reported results are based on the ash content of the samples excluding the carbon. Heavy metals, which were below the detection limit in one of the size fractions, are not included in the table. Their concentration in the ash sample were: As $0.6 \mathrm{mg} / \mathrm{kg}, \mathrm{Bi} 1 \mathrm{mg} / \mathrm{kg}, \mathrm{Cd} 3.1 \mathrm{mg} / \mathrm{kg}$, $\mathrm{Co} 8 \mathrm{mg} / \mathrm{kg}, \mathrm{Hg} 1.1 \mathrm{mg} / \mathrm{kg}$, Sb $8.8 \mathrm{mg} / \mathrm{kg}$, and Sn $7.7 \mathrm{mg} / \mathrm{kg}$. The composition of the ash is within the reported range for miscanthus ash $[8,9,18,19]$. The concentrations of the heavy metals in the ash (As, $\mathrm{Cd}, \mathrm{Cr}, \mathrm{Cu}, \mathrm{Ni}, \mathrm{Pb}$, and $\mathrm{Zn}$ ) were significantly below the limit values for use of the ash as a soil conditioner while the concentration of $\mathrm{Hg}$ was at the limit [12-14].

In comparison to combined bottom and cyclone ashes from the combustion of wood, where the concentration of $\mathrm{K}_{2} \mathrm{O}$ is typically in the range of $3 \%$ to $7 \%$ [26,27], the $\mathrm{K}_{2} \mathrm{O}$ concentration of the miscanthus ash was considerably higher $(14.1 \%)$. The concentrations of $\mathrm{Mg}, \mathrm{Cl}$, and $\mathrm{S}$ in the miscanthus ash were also higher, while the concentrations of $\mathrm{Ca}, \mathrm{Al}, \mathrm{Fe}$, and $\mathrm{Mn}$ were lower [27]. The concentration of most of the heavy metals was in a similar range, as reported for wood combustion ash [27].

For the plant nutrients $\mathrm{P}, \mathrm{K}, \mathrm{Ca}$, and $\mathrm{Mg} \mathrm{I}_{\text {geo }}$ was $4.5,1.7,1.0$, and 0.8 , respectively. The results support the use of the ash as soil conditioner. The highest values of the $I_{\text {geo }}$ were found for $\mathrm{Sb}$ and $\mathrm{Cd}$ in the range $4<I_{\text {geo }} \leq 5$. This is mainly due to the low mean concentration of these elements in the upper continental crust [24]. For Bi, Mo, and $\mathrm{Zn}$, the value of $I_{\text {geo }}$ was in the range $2<I_{\text {geo }} \leq 3$. For the other components, the ash was moderately polluted or less. For $\mathrm{Mn}$ and $\mathrm{Cu}$, it was in the range $1<I_{\text {geo }} \leq 2$ and, for $\mathrm{Cr}$ and $\mathrm{Ni}$, it was $0<I_{\text {geo }} \leq 1$. For all other heavy metals, $I_{\text {geo }}$ was below zero.

The chemical analysis of the ash size fractions produced in the classification procedure are summarized in Tables 2 and 3. The main components (Table 2) are given as oxides. The concentrations of these elements in the ash sample were within the range of reported data $[8,9,19,28]$. The concentrations of heavy metals and other minor elements are summarized in Table 3.

In the air classification procedure, the recovery rate RR was good for most of the elements, which were present in a concentration above the limit of quantification. The recovery rate for these elements was within the range of $90 \%$ to $110 \%$. Exceptions occurred for the elements $\mathrm{Br}, \mathrm{Fe}$, and $\mathrm{Tl}$, where the recovery rate was higher than $110 \%$ and for the elements $\mathrm{Ga}$, Ta, and $\mathrm{Y}$, where it was lower than 
$90 \%$. The calculated recovery for $\mathrm{Cr}, \mathrm{Ni}$, and Mo is significantly higher than $100 \%$. However, these values are not representative because they were caused by a contamination of the classified samples by some erosion of stainless steel material from the classifier [29]. The concentrations of $\mathrm{Cr}, \mathrm{Ni}$, and Mo in the miscanthus ash sample were $86 \mathrm{mg} / \mathrm{kg}, 40 \mathrm{mg} / \mathrm{kg}$, and $16.7 \mathrm{mg} / \mathrm{kg}$, respectively, while the concentrations in all size fractions were considerably higher. Therefore, these components were not included in Table 3. For Fe, this effect can be ignored because the Fe content in the ash is two orders of magnitude higher. The concentration of $\mathrm{Na}$ and of the heavy metals $\mathrm{As}, \mathrm{Bi}, \mathrm{Cd}, \mathrm{Co}, \mathrm{Hg}, \mathrm{Sb}$, and $\mathrm{Sn}$ was below the limit of quantification in all or most of the size fractions.

Table 2. Concentration of main components in the fly ash size fractions (in \% d.m.).

\begin{tabular}{cccccccccc}
\hline Component & Ash & SF 1 & SF 2 & SF 3 & SF 4 & SF 5 & RR $^{\mathbf{a}}$ & $N^{\mathbf{b}}$ & $\boldsymbol{R}^{\mathbf{2} \mathbf{c}}$ \\
\hline $\mathrm{Al}_{2} \mathrm{O}_{3}$ & 0.90 & 0.77 & 1.02 & 0.99 & 0.99 & 0.99 & 1.08 & -0.05 & 0.43 \\
$\mathrm{Fe}_{2} \mathrm{O}_{3}$ & 1.00 & 2.08 & 2.83 & 1.80 & 1.02 & 0.72 & 1.16 & 0.34 & 0.78 \\
$\mathrm{SiO}_{2}$ & 57.9 & 24.2 & 43.8 & 60.2 & 63.1 & 61.0 & 1.00 & -0.24 & 0.74 \\
$\mathrm{TiO}_{2}$ & 0.06 & 0.04 & 0.06 & 0.06 & 0.06 & 0.06 & 1.02 & -0.12 & 0.55 \\
$\mathrm{CaO}$ & 11.1 & 19.7 & 14.5 & 10.1 & 9.83 & 9.95 & 0.98 & 0.19 & 0.80 \\
$\mathrm{MgO}$ & 5.07 & 10.6 & 6.20 & 4.71 & 4.78 & 5.21 & 1.08 & 0.19 & 0.62 \\
$\mathrm{MnO}$ & 0.38 & 0.58 & 0.43 & 0.32 & 0.32 & 0.35 & 0.94 & 0.15 & 0.66 \\
$\mathrm{~K}_{2} \mathrm{O}$ & 14.1 & 18.7 & 16.3 & 13.0 & 12.8 & 13.9 & 1.00 & 0.09 & 0.65 \\
$\mathrm{P}_{2} \mathrm{O}_{5}$ & 4.75 & 9.86 & 5.41 & 3.68 & 3.50 & 3.95 & 0.90 & 0.25 & 0.69 \\
$\mathrm{SO}_{3}$ & 3.75 & 10.8 & 7.39 & 3.93 & 2.81 & 3.06 & 1.04 & 0.38 & 0.86 \\
$\mathrm{Cl}$ & 0.96 & 2.65 & 2.03 & 1.13 & 0.73 & 0.85 & 1.10 & 0.36 & 0.85 \\
\hline
\end{tabular}

${ }^{\mathrm{a}} \mathrm{RR}$ recovery rate. ${ }^{\mathrm{b}} \mathrm{N}$ exponent in the linear regression. ${ }^{\mathrm{c}} r^{2}$ correlation coefficient.

Table 3. Concentration of heavy metals and other minor elements in the fly ash size fractions (in $\mathrm{mg} / \mathrm{kg}$ d.m.).

\begin{tabular}{cccccccccc}
\hline Component & Ash & SF 1 & SF 2 & SF 3 & SF 4 & SF 5 & RR $^{\mathbf{a}}$ & $\mathbf{N}^{\mathbf{b}}$ & $\boldsymbol{r}^{\mathbf{2}}$ \\
\hline $\mathrm{Ba}$ & 249 & 265 & 205 & 237 & 289 & 287 & 1.10 & -0.052 & 0.27 \\
$\mathrm{Br}$ & 70.2 & 233 & 191 & 113 & 58.1 & 65.2 & 1.26 & 0.407 & 0.88 \\
$\mathrm{Cu}$ & 92.8 & 135 & 124 & 102 & 92.4 & 98.6 & 1.09 & 0.099 & 0.78 \\
$\mathrm{Ga}$ & 5.6 & 4.1 & 4.1 & 1.9 & 5.6 & 5.1 & 0.85 & -0.081 & 0.07 \\
$\mathrm{Ge}$ & 1.1 & 2.7 & 0.9 & 0.2 & 1.2 & 0.9 & 0.93 & 0.218 & 0.11 \\
$\mathrm{~Pb}$ & 15.4 & 64.1 & 36.2 & 25.1 & 15.2 & 5.3 & 1.04 & 0.653 & 0.97 \\
$\mathrm{Rb}$ & 66.9 & 45.5 & 54 & 61 & 64.6 & 66.5 & 0.94 & -0.104 & 0.91 \\
$\mathrm{Se}$ & 2.1 & 6.6 & 4.7 & 2.3 & 1.7 & 1.5 & 1.05 & 0.437 & 0.93 \\
$\mathrm{Sr}$ & 195 & 315 & 222 & 176 & 160 & 178 & 0.95 & 0.161 & 0.72 \\
$\mathrm{Ta}$ & 27.1 & 28.5 & 28 & 29.7 & 20.8 & 22.4 & 0.87 & 0.084 & 0.56 \\
$\mathrm{Th}$ & 4.5 & 5.8 & 5.1 & 4.5 & 3.9 & 4.7 & 1.02 & 0.074 & 0.51 \\
$\mathrm{Tl}$ & 1.0 & 2.3 & 1.7 & 1.6 & 0.5 & 1.2 & 1.17 & 0.268 & 0.43 \\
$\mathrm{~V}$ & 32.9 & 49.9 & 53 & 37.1 & 18.9 & 33.4 & 0.99 & 0.193 & 0.45 \\
$\mathrm{Y}$ & 3.3 & 2 & 2.1 & 2.3 & 2 & 3.6 & 0.86 & -0.129 & 0.55 \\
$\mathrm{Zn}$ & 617 & 882 & 715 & 674 & 543 & 512 & 0.94 & 0.151 & 0.96 \\
\hline
\end{tabular}

${ }^{\mathrm{a}} \mathrm{RR}$ recovery rate. ${ }^{\mathrm{b}} \mathrm{N}$ exponent in the linear regression. ${ }^{\mathrm{c}} r^{2}$ correlation coefficient.

For most elements, the concentrations did not differ very much between the various size fractions. The exponent $N$ for each component, which expresses the size dependence of the concentration and the correlation coefficient $r^{2}$ were obtained by linear regression (Tables 2 and 3). For $\mathrm{K}$, the exponent was close to zero $(N=0.09)$, which indicates that there is only very little size dependence of the concentration. This is in contrast to results found for wood combustion fly ash, where the exponent for $\mathrm{K}$ was 0.47 [21] and 0.68 [20]. For most other elements, the size dependence of the concentration was low, too. The exponent $N$ was in a range from -0.2 to 0.2 for $\mathrm{Al}, \mathrm{Ba}, \mathrm{Ca}, \mathrm{Cu}, \mathrm{Ga}, \mathrm{Mg}, \mathrm{Mn}, \mathrm{Rb}, \mathrm{Sr}$, $\mathrm{Ta}, \mathrm{Th}, \mathrm{Ti}, \mathrm{V}, \mathrm{Y}$, and $\mathrm{Zn}$. For some elements, a higher size dependence of the concentration was found. 
The exponent $N$ was $>0.2$ for $\mathrm{Pb}, \mathrm{Se}, \mathrm{Br}, \mathrm{S}, \mathrm{Cl}, \mathrm{Fe}, \mathrm{Tl}, \mathrm{P}$, and $\mathrm{Ge}$, while only for $\mathrm{Si}$ was the exponent markedly negative $(-0.24)$.

In Figure 3, the size dependence of the concentration $\mathrm{K}, \mathrm{S}, \mathrm{Cl}$, and some heavy metals $(\mathrm{Cu}, \mathrm{Pb}$, and $\mathrm{Zn}$ ) is shown to be expressed by the calculated enrichment factor. Corresponding to the highest value of the exponent $N$, the highest value of the EF in the finest size fraction (4.2) and the lowest for the coarse size fraction (0.34) were found for $\mathrm{Pb}$.

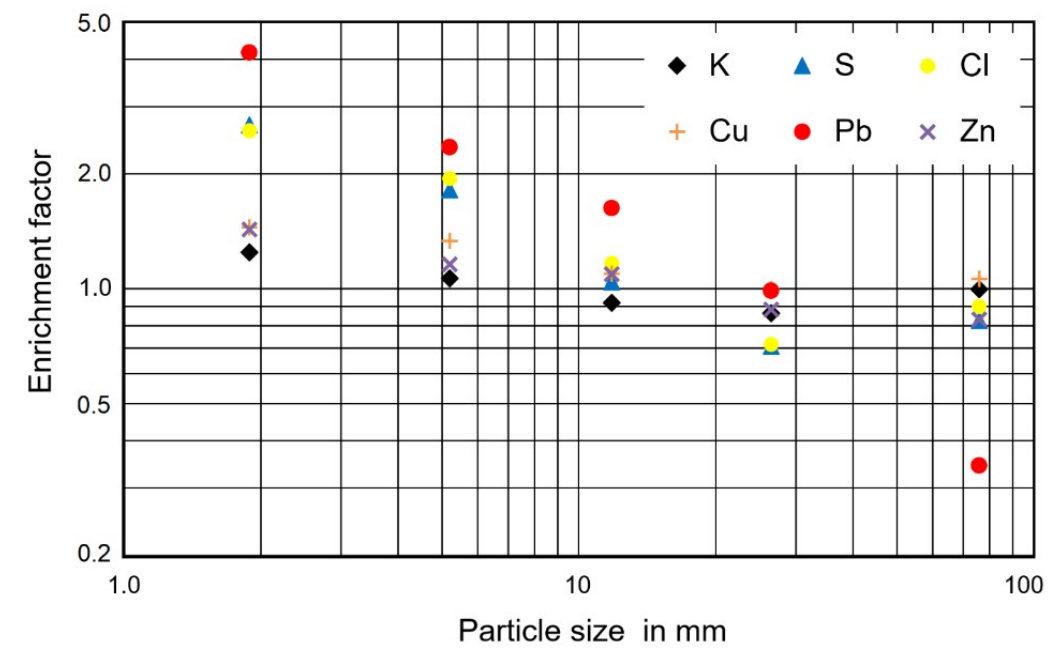

Figure 3. Size dependence of the concentration of various components.

Ashes can be assigned to certain basic types: $\mathrm{S}$ type, $\mathrm{C}$ type, $\mathrm{K}$ type, and CK type [30]. This can be displayed in a triangular diagram. In Figure 4, the different size fractions of the ash are shown in such a diagram. While the ash sample and the three coarser size fractions are within the area of the $S$ type ashes, the two finest size fractions are $\mathrm{CK}$ and $\mathrm{K}$ type ashes.

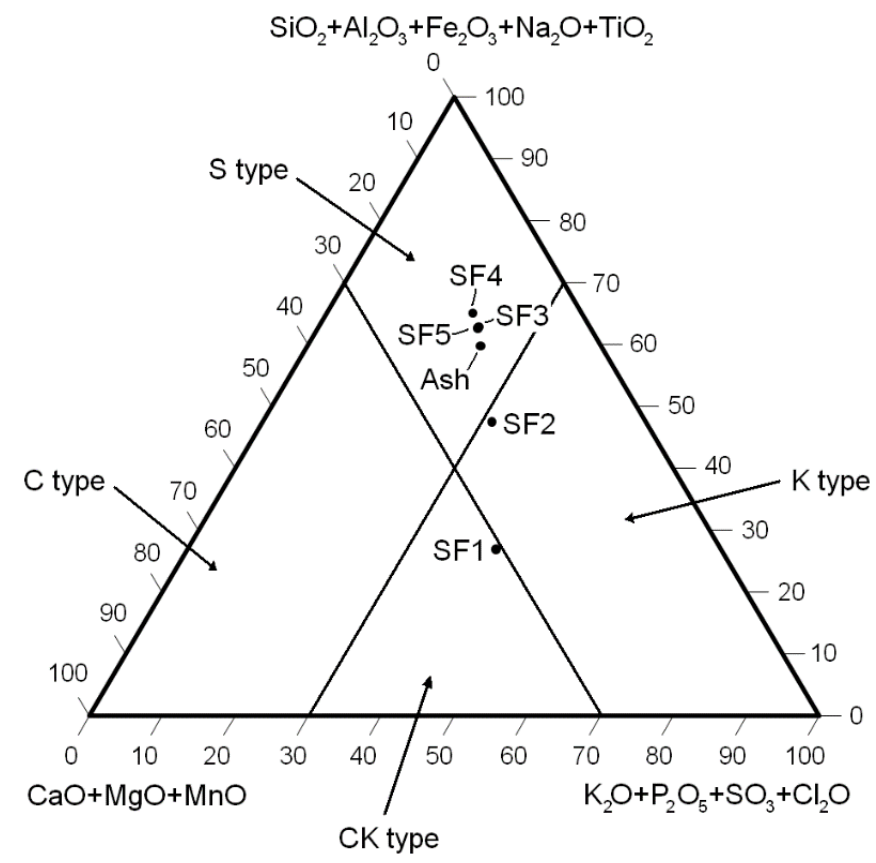

Figure 4. Triangular ash diagram with the different size fractions.

In order to verify the low enrichment of $\mathrm{K}$ and other elements in the fine size fraction, a second ash sample was investigated, which originated from another combustion plant that uses miscanthus 
as fuel. The ash sample was also classified into size fractions, which were analyzed for a reduced number of elements. Figure 5 shows the comparison of the exponents $N$ obtained for this additional ash sample in comparison with the investigated ash. For most elements, the value of the exponent was similar. Only for $\mathrm{Si}, \mathrm{Fe}, \mathrm{Cu}$, and $\mathrm{Zn}$ was a distinct difference observed.

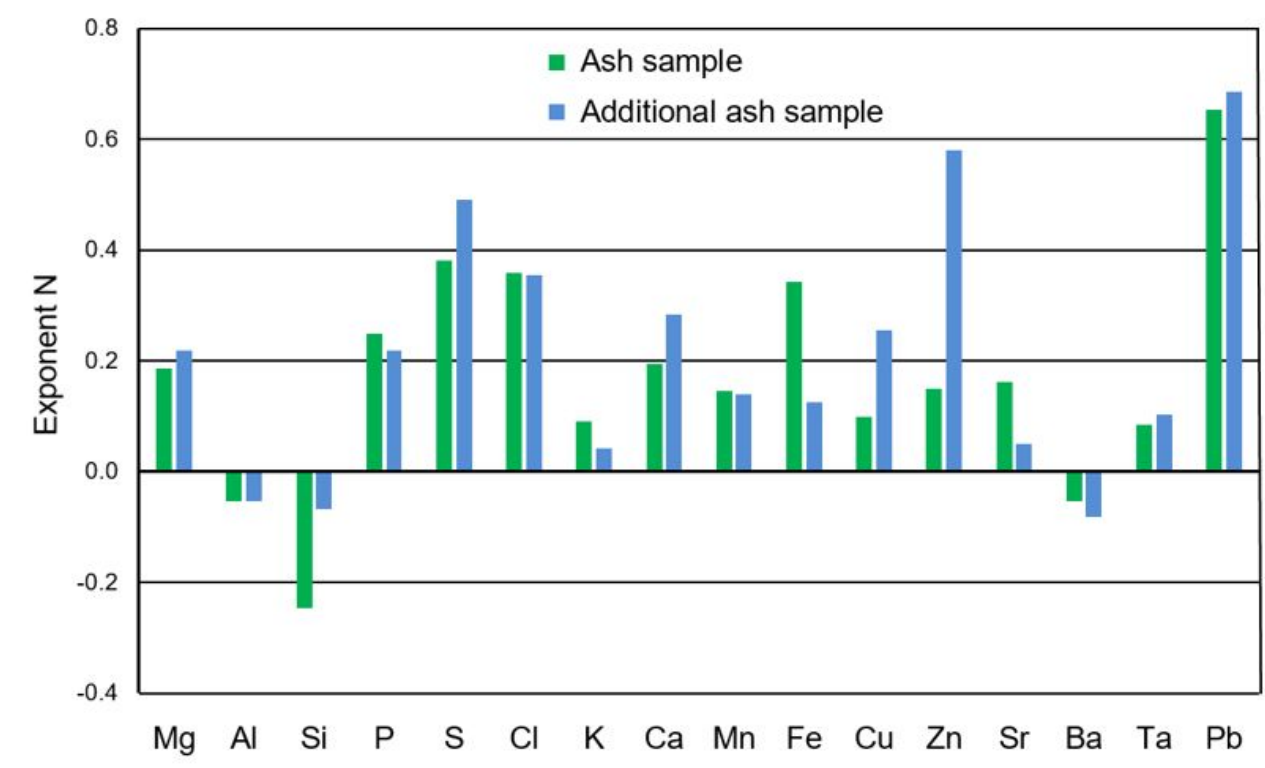

Figure 5. Comparison of the exponents of the two ashes.

\subsection{Reasons for the Low Enrichment Potassium in the Fine Size Fractions of the Ash}

The behavior of $\mathrm{K}$ in ashes from biomass combustion and its distribution between different phases is rather complicated [31]. The results of theoretical equilibrium calculations using approximate gas and ash composition from the present study are summarized in Figure 6. These results can give some indication only because equilibrium will not be reached because of the short residence time in the system. In the diagram, the solid lines show the solid and liquid components while the dashed lines show the gaseous components. The stable potassium components at lower temperatures are solid $\mathrm{KCl}$, $\mathrm{K}_{2} \mathrm{SO}_{4}$, and $\mathrm{K}_{2} \mathrm{Si}_{4} \mathrm{O}_{9}$. With increasing temperature, the fraction of $\mathrm{K}_{2} \mathrm{SO}_{4}$ decreases while the fraction of $\mathrm{K}_{2} \mathrm{Si}_{4} \mathrm{O}_{9}$ increases. Recognizable portions of $\mathrm{K}$ were volatilized only at temperatures above $900{ }^{\circ} \mathrm{C}$. This corresponds well with published results [32]. At $1300{ }^{\circ} \mathrm{C}$, approximately $10 \%$ of $\mathrm{K}$ is in the gas phase. The volatile components are $\mathrm{KCl}$ and, to a lesser extent, $\mathrm{KOH} . \mathrm{K}_{2} \mathrm{O}$ is practically not present at equilibrium, neither in the solid phase, nor in the gaseous phase.

In the miscanthus ash, the molar ratio of $\mathrm{K}$ to $\mathrm{Cl} n_{K} / n_{C l}$ was approximately 11 . Thus, the volatilization of $\mathrm{K}$ in the form of $\mathrm{KCl}$ is quite limited. In wood combustion ash, the molar ratio of $\mathrm{K}$ to $\mathrm{Cl}$ is somewhat lower. Reported values are in the range of 4.3 [33] to 7.3 [21]. Therefore, higher rates of $\mathrm{K}$ volatilization are possible for wood combustion ash.

Silicates like $\mathrm{K}_{2} \mathrm{Si}_{4} \mathrm{O}_{9}$ can bind $\mathrm{K}$ effectively because of their thermal stability and low volatility [34]. In the miscanthus ash, the molar ratio of $\mathrm{K}$ to $\mathrm{Si} n_{K} / n_{S i}$ was 0.31 . In comparison, values of this ratio in the range of 0.35 to 2.5 have been reported for wood combustion ashes [35]. Thus, less K can be fixed in silicates. Similar observations were made for ash from the combustion of straw [36]. The differences in ash chemistry are also visible in the triangular ash diagram (Figure 4). The ash from the combustion of miscanthus is located in the $S$ type area, while typical wood combustion ash is located in the C type area [30].

In wood combustion studies, the temperature measured above the grate was approximately $300{ }^{\circ} \mathrm{C}$ higher $[21,27]$. In addition, in the study that investigated the production of K-enriched ash for fertilizer production [16], the gas temperature was significantly higher $\left(790\right.$ to $890^{\circ} \mathrm{C}$ at the furnace outlet). Thus, the most reasonable explanations for the absence of $\mathrm{K}$ enrichment in the fine ash fractions 
in miscanthus ash are the different ash chemistry, especially the low $\mathrm{Cl}$ content combined with the higher $\mathrm{Si}$ content, and the significantly lower combustion temperature in the miscanthus combustion plant in comparison to wood combustion plants.

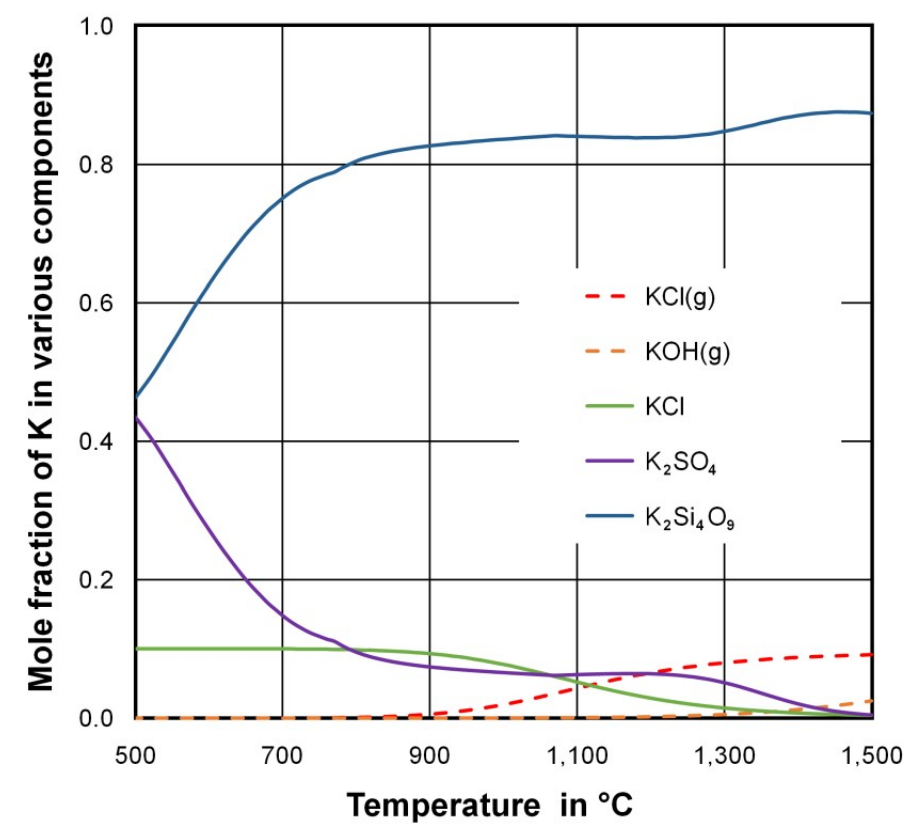

Figure 6. Equilibrium distribution of potassium on various components and phases as a function of the temperature.

\subsection{Consequences for Ash Utilization}

The plant nutrients $\mathrm{Ca}$ and $\mathrm{Mg}$ were quite uniformly distributed in the miscanthus ash with some enrichment only in the finest size fraction. The exponents were close to zero, which corresponds well with the reported data for wood ash $[20,21]$. For the plant nutrient $P$, a slight enrichment in the fine size fractions was found. The exponent was 0.23 . In wood combustion, higher enrichment of $\mathrm{P}$ in the fine size fractions of the ash was found [37]. However, no exponent for the enrichment was calculated in this study.

Significantly increased concentrations in the fine fractions were found only for the elements $\mathrm{Pb}$, $\mathrm{Se}, \mathrm{Br}, \mathrm{S}, \mathrm{Cl}$, and $\mathrm{Fe}$. The respective exponents $N$ were $0.65,0.44,0.41,0.36,0.34$, and 0.32 . For wood combustion fly ash, the reported exponents for $\mathrm{S}$ and $\mathrm{Cl}$ were substantially higher $(N=0.56$ and 0.77) [21]. The enrichment of $\mathrm{Pb}$ in the fine size fractions was in a similar range as reported for wood combustion ash $(N=0.72$ [20] and $N=0.58$ [21]). For wood ash, the exponent for Fe was negative while, for $\mathrm{Br}$ and $\mathrm{Se}$, no data are available [21]. The heavy metals $\mathrm{Cu}$ and $\mathrm{Zn}$ were very slightly enriched in the miscanthus ash. The respective exponents were 0.10 and 0.15 . In comparison, the respective exponents in wood combustion fly ash were significantly higher (0.29 and 0.54) [21].

The only element in the miscanthus ash with a highly negative exponent was $\mathrm{Si}(N=-0.27)$. In wood combustion fly ash, the depletion of $\mathrm{Si}$ in the fine fractions was much more pronounced $(N=-1.02)$.

\section{Discussion}

The ash from the miscanthus combustion plant was slightly contaminated by heavy metals. The concentrations of all limited heavy metals were well below the limit concentrations for use as a soil conditioner on agricultural land and forests. Expressed by the Geoaccumulation Index, the highest pollution level was found for $\mathrm{Sb}$ and $\mathrm{Cd}$ followed by $\mathrm{Bi}, \mathrm{Mo}, \mathrm{Zn}, \mathrm{Mn}, \mathrm{Cu}, \mathrm{Cr}$, and Ni. For all other heavy metals, $I_{g e o}$ was in the range of "unpolluted". 
For the plant nutrients $\mathrm{P}, \mathrm{K}, \mathrm{Ca}$, and $\mathrm{Mg}$, $\mathrm{I} g e o_{\text {oo }}$ was $4.5,1.7,1.0$, and 0.8 , respectively. The low values support the use of the ash as soil conditioner.

The potassium concentration in miscanthus ash $\left(14.1 \% \mathrm{~K}_{2} \mathrm{O}\right)$ is significantly higher than in the ash from wood combustion ( $3 \%$ to $7 \% \mathrm{~K}_{2} \mathrm{O}$ ). In comparison to wood ash, there is only very little enrichment of $\mathrm{K}$ in the fine size fractions of the ash. Therefore, the production of a K-rich material for the production of potassium fertilizer by classification is not feasible. The most plausible explanation for the absence of such an enrichment, which has been reported for wood ash is, besides the significantly lower combustion temperature in the miscanthus combustion plant, a significant difference in the ash chemistry, especially the low $\mathrm{Cl}$ and the high $\mathrm{Si}$ content. Based on the low heavy metal content and the missing enrichment of $\mathrm{K}$ in the fine size fractions, the most sensible use of miscanthus ash is its direct recycling to the soil such as where the miscanthus plants are grown.

\section{Conclusions}

The following conclusions can be drawn from the results of the study:

(a) Ash from the combustion of miscanthus contains plant nutrients (K, P, Ca) and is relatively low contaminated with heavy metals. The use of the ash as soil conditioner on forest and agricultural land is feasible, especially on the land where the miscanthus was grown.

(b) The production of a K-rich fraction out of the ash by classification as a source of $\mathrm{K}$ for fertilizer production is not applicable because of the low size dependence of the $\mathrm{K}$ concentration.

(c) The reasons for the limited enrichment of $\mathrm{K}$ in the fine size fractions can be found in the ash chemistry, especially the low $\mathrm{Cl}$ content combined with the high Si content and in the low combustion temperature.

Funding: This research received no external funding.

Acknowledgments: The preparation of scanning electron microscope images by M. Gillich and XRF analysis by P. Ortbauer are gratefully acknowledged. The provision of the ash sample by the company Miscanthus Farm is also acknowledged.

Conflicts of Interest: The author declares no conflict of interest.

\section{References}

1. Lewandowski, I.; Kicherer, A.; Vonier, P. $\mathrm{CO}_{2}$-Balance for the cultivation and combustion of Miscanthus. Biomass Bioenergy 1995, 8, 81-90. [CrossRef]

2. Lewandowski, I.; Scurlock, J.M.O.; Lindvall, E.; Christou, M. The development and current status of perennial rhizomatous grasses as energy crops in the US and Europe. Biomass Bioenergy 2003, 25, 335-361. [CrossRef]

3. Baxter, X.C.; Darvell, L.I.; Jones, J.M.; Barraclough, T.; Yates, N.E.; Shield, I. Miscanthus combustion properties and variations with Miscanthus agronomy. Fuel 2014, 117, 851-869. [CrossRef]

4. Chou, C.-H. Miscanthus plants used as an alternative biofuel material: The basic studies on ecology and molecular evolution. Renew. Energy 2009, 34, 1908-1912. [CrossRef]

5. Lewandowski, I.; Clifton-Brown, J.; Trindade, L.M.; van der Linden, G.C.; Schwarz, K.-U.; Müller-Sämann, K.; Anisimov, A.; Chen, C.-L.; Dolstra, O.; Donnison, I.S.; et al. Progress on Optimizing Miscanthus Biomass Production for the European Bioeconomy: Results of the EU FP7 Project OPTIMISC. Front. Plant Sci. 2016, 7, 1620. [CrossRef] [PubMed]

6. Statistik Austria. 2016. Available online: http://www.statistik.at/web_de/statistiken/index.html (accessed on 8 August 2017).

7. Frühwirth, P.; Liebhard, P. Miscanthus sinensis 'Giganteus'. Produktion, Inhaltsstoffe und Verwertung; Landwirtschaftskammer Österreich, Bundes-LFI: Wien, Austria, 2006; pp. 7-47.

8. Baxter, X.C.; Darvell, L.I.; Jones, J.M.; Barraclough, T.; Yates, N.E.; Shield, I. Study of Miscanthus x giganteus ash composition—Variation with agronomy and assessment method. Fuel 2012, 95, 50-62. [CrossRef] 
9. Michel, R.; Kaknics, J.; Bouchetou, M.L.; Gratuze, B.; Balland, M.; Hubert, J.; Poirier, J. Physicochemical changes in Miscanthus ash on agglomeration with fluidized bed material. Chem. Eng. J. 2012, 207-208, 497-503. [CrossRef]

10. European Biomass Association. European Bioenergy Outlook 2013; Statistical Report; AEBIOM: Brussels, Belgium, 2013; pp. 108-109.

11. Van der Weijde, T.; Kiesel, A.; Iqbal, Y.; Muylle, H.; Dolstra, O.; Visser, R.G.F.; Lewandowski, I.; Trindade, L.M. Evaluation of Miscanthus sinensis biomass quality as feedstock for conversion into different bioenergy products. GCB Bioenergy 2017, 9, 176-190. [CrossRef]

12. Emilsson, S. International Handbook-From Extraction of Forest Fuels to Ash Recycling; Swedish Forest Agency: Jönköping, Sweden, 2006.

13. Bundesministerium für Land- und Forstwirtschaft, Umwelt und Wasserwirtschaft Richtlinien für den sachgerechten Einsatz von Pflanzenaschen zur Verwertung auf land- und forstwirtschaftlich genutzten Flächen; Bundesministerium für Land- und Forstwirtschaft, Umwelt und Wasserwirtschaft: Vienna, Austria, 2011.

14. Nurmesniemi, H.; Mäkelä, M.; Pöykiö, R.; Manskinen, K.; Dahl, O. Comparison of the forest fertilizer properties of ash fractions from two power plants of pulp and paper mills incinerating biomass-based fuels. Fuel Process. Technol. 2012, 104, 1-6. [CrossRef]

15. Von Wilpert, K.; Bösch, B.; Puhlmann, H.; Zirlewagen, D. Wood ash recycling-an appropriate measure to close nutrient cycles in forests. In Proceedings of the 4th Central European Biomass Conference, Graz, Austria, 15-18 January 2014; Österreichischer Biomasse Verband: Vienna, Austria, 2014; p. 61.

16. Saletnik, B.; Zagula, G.; Bajcar, M.; Czernicka, M.; Puchalski, C. Biochar and Biomass Ash as a Soil Ameliorant: The Effect on Selected Soil Properties and Yield of Giant Miscanthus (Miscanthus x giganteus). Energies 2018, 11, 2535. [CrossRef]

17. Maeda, N.; Katakura, T.; Fukasawa, T.; Huang, A.-N.; Kawano, T.; Fukui, K. Morphology of woody biomass combustion ash and enrichment of potassium components by particle size classification. Fuel Process. Technol. 2017, 156, 1-8. [CrossRef]

18. Obernberger, I.; Brunner, T.; Bärnthaler, G. Chemical properties of solid biofuels—Significance and impact. Biomass Bioenergy 2006, 30, 973-982. [CrossRef]

19. Lanzerstorfer, C. Chemical composition and properties of ashes from combustion plants using Miscanthus as fuel. J. Environ. Sci. 2017, 54, 178-183. [CrossRef] [PubMed]

20. Lanzerstorfer, C. Model based prediction of required cut size diameter for fractionation of fly ash from a grate-fired wood chips incineration plant. Fuel Process. Technol. 2011, 92, 1095-1100. [CrossRef]

21. Lanzerstorfer, C. Cyclone fly ash from a grate-fired biomass combustion plant: Dependence of the concentration of various components on the particle size. Fuel Process. Technol. 2015, 131, 382-388. [CrossRef]

22. Lanzerstorfer, C.; Kröppl, M. Air classification of blast furnace dust collected in a fabric filter for recycling to the sinter process. Resour. Conserv. Recycl. 2014, 86, 132-137. [CrossRef]

23. Müller, G. Index of geo-accumulation in sediments of the Rhine River. Geochem. J. 1969, 2, 108-118.

24. Taylor, S.R.; Mclennan, S.M. The geochemical evolution of the continental crust. Rev. Geophys. 1995, 33, 241-265. [CrossRef]

25. Linak, W.P.; Wendt, J.O.L. Toxic metal emissions from incineration: Mechanisms and control. Prog. Energy Combust Sci. 1993, 119, 145-185. [CrossRef]

26. Van Loo, S.; Koppejan, J. The Handbook of Biomass Combustion and Co-Firing; Earthscan: London, UK, 2008; pp. 350-353. ISBN 1-84407-249-5.

27. Lanzerstorfer, C. Grate-fired biomass combustion plants using forest residues as fuel: Enrichment factors for components in the fly ash. Waste Biomass Valoriz. 2017, 8, 235-240. [CrossRef]

28. Zevenhoven-Onderwater, M.; Backman, R.; Skrifvars, B.-J.; Hupa, M. The ash chemistry in fluidized bed gasification of biomass fuels. Part I: Predicting the chemistry of melting ashes and ash-bed material interaction. Fuel 2001, 80, 1489-1502. [CrossRef]

29. Lanzerstorfer, C. Investigation of the contamination of a fly ash sample during sample preparation by classification. Int. J. Environ. Sci. Technol. 2015, 12, 1437-1442. [CrossRef]

30. Vassilev, S.V.; Vassileva, C.G.; Baxter, D. Trace element concentrations and associations in some biomass ashes. Fuel 2014, 129, 292-313. [CrossRef] 
31. Niu, Y.; Tan, H.; Hui, S. Ash-related issues during biomass combustion: Alkali-induced slagging, silicate melt-induced slagging (ash fusion) agglomeration, corrosion, ash utilization, and related countermeasures. Prog. Energ. Combust. 2016, 52, 1-62. [CrossRef]

32. Kaknics, J.; Michel, R.; Poirier, J. Miscanthus ash transformation and interaction with bed materials at high temperature. Fuel Process. Technol. 2016, 141, 178-184. [CrossRef]

33. Steenari, B.-M.; Schelander, S.; Lindqvist, O. Chemical and leaching characteristics of ash from combustion of coal, peat and wood in a 12 MW CFB-A comparative study. Fuel 1999, 78, 249-258. [CrossRef]

34. Knudsen, J.N.; Jensen, P.A.; Dam-Johansen, K. Transformation and release tot he gas phase of $\mathrm{Cl}, \mathrm{K}$ and $\mathrm{S}$ during combustion of annual biomass. Energy Fuels 2004, 18, 1385-1399. [CrossRef]

35. Steenari, B.-M.; Lindqvist, O. Stabilisation of biofuel ashes for recycling to forest soil. Biomass Bioenergy 1997, 13, 39-50. [CrossRef]

36. Wei, X.; Schnell, U.; Hein, K.R.G. Behaviour of gaseous chlorine and alkali metals during biomass thermal utilization. Fuel 2005, 84, 841-848. [CrossRef]

37. Budhathoki, R.; Väisänen, A. Particle size based recovery of phosphorus from combined peat and wood fly ash for forest fertilization. Fuel Process. Technol. 2016, 146, 85-89. [CrossRef]

(C) 2019 by the author. Licensee MDPI, Basel, Switzerland. This article is an open access article distributed under the terms and conditions of the Creative Commons Attribution (CC BY) license (http://creativecommons.org/licenses/by/4.0/). 